\title{
NEW FIND OF STEGODON SOMPOENSIS MAXILLA FROM CIANGKANGE, SOPPENG, SOUTH SULAWESI
}

\author{
Penemuan Rahang Atas Stegodon Sompoensis dari Ciangkange, \\ Soppeng, Sulawesi Selatan \\ Unggul Prasetyo Wibowo ${ }^{1 a}$, Budianto Hakim ${ }^{2 b}$, Andi Muhammad Saiful ${ }^{2 c}$ \\ ${ }^{1}$ Museum Geologi \\ Jl. Diponegoro No. 57 Bandung, Jawa Barat, Indonesia \\ ${ }^{2}$ Balai Arkeologi Sulawesi Selatan \\ Jl. Pajjaiyang No. 13 Sudiang Raya Makassar, Indonesia \\ auungpw@yahoo.com \\ bbudiantohakim@kemdikbud.go.id \\ ciful_fullah@yahoo.co.id
}

Received: 03/05/2019; revisions: 16/11-27/11/2019; accepted: 28/11/2019

Published online: 28/11/2019

\begin{abstract}
Abstrak
Pulau Sulawesi di Indonesia terletak di daerah Wallacea. Secara geologi pulau ini berada di antara Asia (paparan Sunda) dan Australia (paparan Sahul). Sebagai bagian dari kepulauan Wallacea, Sulawesi merupakan pulau yang memiliki kompleksitas baik dari segi biologi maupun geologinya. Meskipun fauna-fauna vertebrata kuarter Sulawesi sudah dideskripsi, tetapi sejarah dan pola biogeografi di pulau ini masih sangat kurang, karena sedikitnya fosil-fosil yang ditemukan. Tulisan ini mendeskripsikan fragmen maxilla dari gajah purba jenis Stegodon dengan akar gigi molar $M^{1}$ yang ditemukan di perlapisan batupasir konglomeratan, di daerah Ciangkange, sekitar situs arkeologi Cabenge, Sulawesi Selatan, Indonesia. Berdasarkan perbandingan data pengukuran spesimen ini dengan Stegodon sompoensis dan Stegodon trigonocephalus maka disimpulkan bahwa fragmen maksila Stegodon ini berasal dari Stegodon sompoensis, jenis Stegodon kerdil dari Pulau Sulawesi. Spesimen ini merupakan temuan permukaan, tetapi berdasarkan matriks sedimen yang masih menempel di maxilla, spesimen ini diinterpretasikan berasal dari Anggota Beru subunit A. Stegodon sompoensis ini diperkirakan dahulu hidup di lingkungan lagoon dekat pantai pada sekitar 2,5 juta tahun yang lalu atau Pliosen Akhir sampai Pleistosen Awal. Penentuan umur ini didasarkan pada boistratigrafi fauna vertebrata Sulawesi Selatan.
\end{abstract}

Kata Kunci: Stegodon sompoensis, maksila, Pliosen Akhir-Pleistosen Awal, fosil, Sulawesi Selatan.

\begin{abstract}
Sulawesi is an island located in the Wallacean region of Indonesia. Geologically its lying midway between the Asian (Sunda) and Greater Australian (Sahul) continents. As a part of Wallacea islands, Sulawesi is an island that shows complexity either in biology or geology perspective. Though the distinctive quaternary vertebrate fauna has been described from Sulawesi, historical pattern of biogeography still poorly understood due to the lack of the fossil specimens. This paper describes a maxilla fragment with molar root teeth $\mathrm{M}^{1}$ from an archaic proboscidae called Stegodon that found in the conglomeratic sandstone layer, at Ciangkange Area, around Cabenge Archeological site of South Sulawesi, Indonesia. Based on the comparation measuring data between this specimen with the Stegodon sompoensis and the Stegodon trigonocephalus it can be concluded that this Stegodon maxilla fragment is belong to the Stegodon sompoensis, a dwarf Stegodon from Sulawesi Island. The specimen is a surface collected sample. Based on the attached matrix on the maxilla fragment, this specimen interpreted to be derived from subunit A of Beru Member, Walanae Formation. This Stegodon sompoensis is likely to be
\end{abstract}


lived near the coastal-lagoon around 2,5 million years ago or Late Pliocene to Early Pleistocene. This estimated specimen age is based on the vertebrate fauna biostratigraphy of South Sulawesi.

Keywords: Stegodon sompoensis, maxilla, Late Pliocene-Early Pleistocene, fossil, South Sulawesi.

\section{INTRODUCTION}

The size of vertebrate animals in an island commonly follows a pattern which it becomes large in small herbivorous animals and becomes dwarfed in large animals, this pattern is to be known by the law of "Island rule" (Raia \& Meiri, 2006, p. 1731; Van, 1973, p. 35). The distinct examples of gigantism and dwarfism on islands are found in the fossil record (Vos, Ostende, \& Van Den Bergh, 2007). This pattern can be observed in areas that have a long history as an island as in Mediterranean islands likes Sardinia, Sicily, Malta, Crete, Cyprus, Tilos, Rhodes, Delos, Serifos, Milos, Kythnos and Naxos (Herridge, 2010, p. 50), Northern
Channel Islands of California likes San Miguel, Santa Rosa and Santa Cruz Island (Agenbroad, 2012, p. 2), Lesser Sunda islands of Indonesia likes Flores, Sumba and Timor (Wibowo, Setiyabudi, Kurniawan, \& Insani, 2015, p. 355) and Sulawesi, Indonesia (Geer, Lyras, Vos, \& Dermitzakis, 2010, p. 1656).

Sulawesi or formerly Celebes Island, is an island that has complexity in its paleogeographic history due to its position lying in the biogeographic crossroads between Asia and Australia (Stelbrink, Albrecht, Hall, \& Rintelen, 2012, p. 2252) (figure 1). This condition causes the fauna

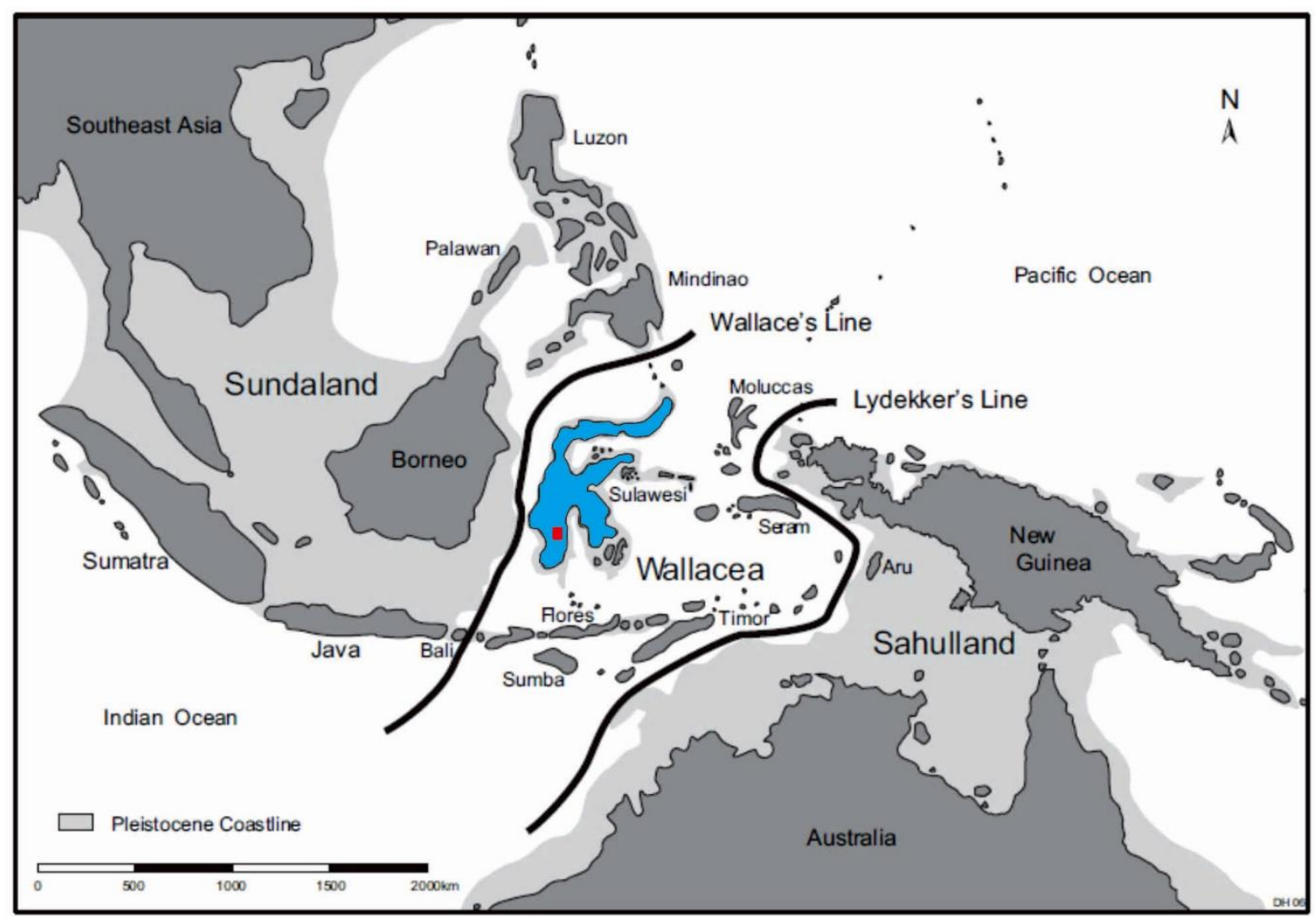

Figure 1. Map of Indonesian Archipelago showing the location of the Wallace line. Sulawesi lies midway between the Asian and Greater Australian continents whereas the Walanae valley indicated by the red square (source: Morwood, et al. 2009: 438, modified) 
show a real endemic level (Rozzi, 2017, p. 188). This endemic phenomenon was noticed by Wallace with his famous zoogeographic boundary called Wallace's Line (Simpson, 1977, p. 108). The other distinct zoogeographic boundary in Indonesian Archipelago besides Wallace's Line is Lydekker's Line (Simpson, 1977, p. 109) and the area between Wallace's Line and Lydekker's Line now called as Wallacea Area (Morwood et al., 2009, p. 438) (figure 1).

One type of fauna which lived in Sulawesi is Proboscidea (elephant family) (Hooijer, 1949, p. 206). In Sulawesi the information on the existence of proboscidea that lived in the past is based on the findings of fossils in paleontological data record. The proboscidean fossils data record in Sulawesi shows that it reported found in Central Sulawesi and South Sulawesi (Brumm et al., 2018, p. 11; Van Den Bergh, Aziz, Sondaar, \& Vos, 1994, p. 22).

The paleontological data in South Sulawesi was begin when the pieces of fossilized fauna vertebrate bones, teeth and a proboscidean molar were discovered together with the flakes of Paleolithic era from the fields around Beru, South Sulawesi (Bartstra, 1997, p. 33). Beru is around Cabenge area that known also contains vertebrate fossils in Sulawesi. Cabenge and its surrounding area is located in Walanae valley, Soppeng, South Sulawesi.

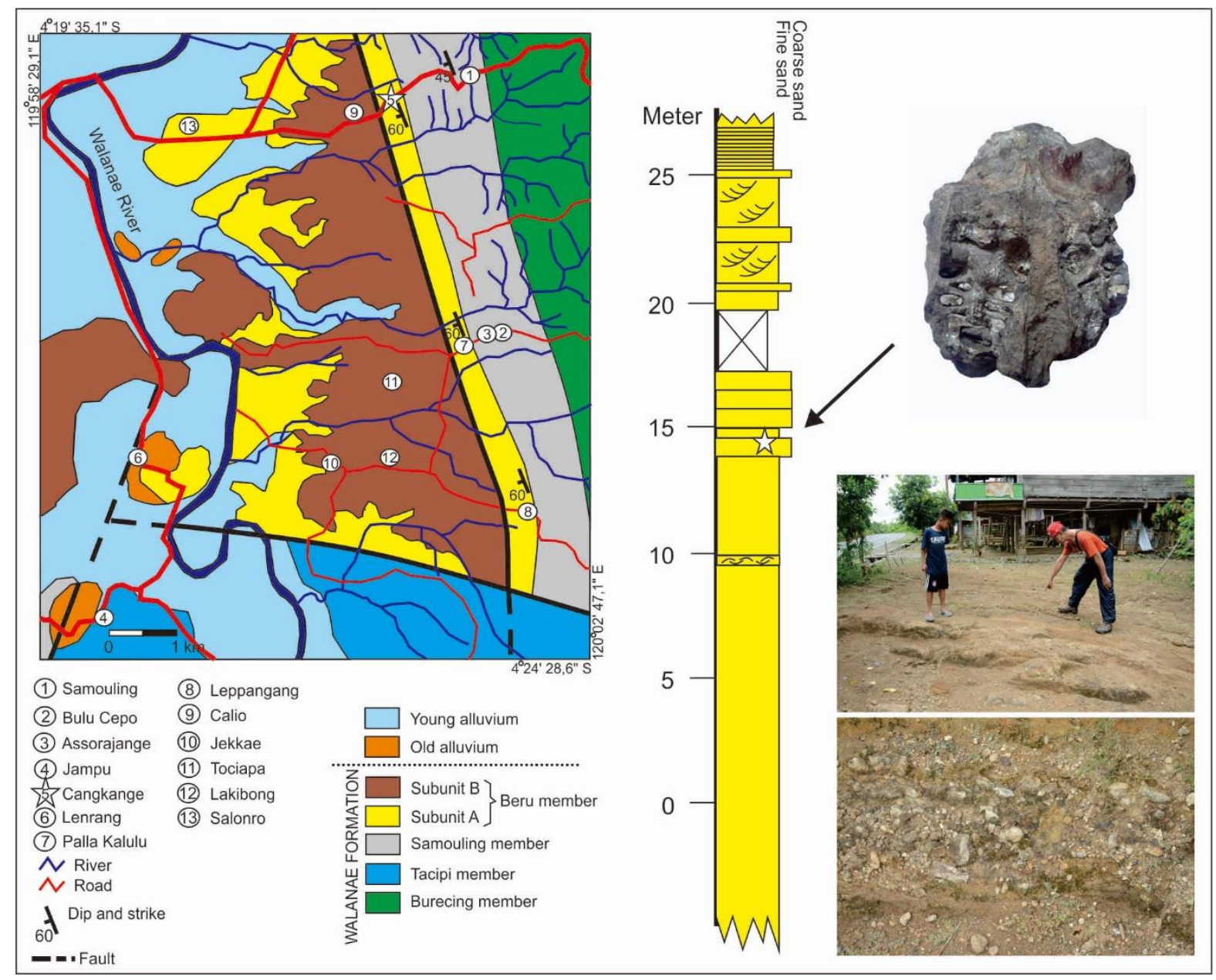

Figure 2. The finding location of BAM-041 indicated by star on geological map and its position in the local stratigraphy (source: Wibowo, 2016). 
Cabenge Site and its surrounding area started to be known since the discovery of stone tool artifacts in the significant amount in this area called "Cabenge Industry" (Bartstra, 1997, p. 40; Heekeren, 1958, p. 77). This discovery become more interesting because the artefacts are associated with the Sulawesi vertebrate fauna that had extinct like dwarf proboscidae Stegodon sompoensis and Elephas celebensis, giant tortoise Megalochelys sp. and archaic pig Celebochoerus heekereni (Bartstra, Hooijer, Kaluppa, \& Akib, 1994, p. 1; Geer \& Van Den Bergh, 2016, p. 208; Hooijer, 1955, p. 89). The latest taxonomy study of Elephas celebensis now revised to Stegoloxodon celebensis (Markov \& Saegusa, 2008, p. 56).

In 2016 the researcher team from Makassar Archeology Office visited Cabenge Site which is administratively located in Lilirilau District, Soppeng Regency, South Sulawesi. Either known by its stone tools, the Cabenge Site and its surrounding area is also known as an area containing the oldest vertebrate fossils in South Sulawesi. On 12 April 2016, the team obtained a maxillary proboscidea fossil fragment in Ciangkange, around Cabenge Site, near Calio Prehistoric Museum (Saiful, Wibowo, Hakim, \& Akib, 2016, p. 73). Its location precisely in the Ciangkange subvillage, Ujung village, Lilirilau district, Soppeng regency (Balai Arkeologi Makassar collection number: BAM-041) (figure 2 and 3). The location of the fossil findings lying in the lithologic layers of exposed conglomerate sandstones in the Ciangkange area (Saiful et al., 2016, p. 73) (figure 2). This study describes the maxillary fragment BAM-041, comparing the results with other proboscidae dental elements, and determining the fossil life and environmental conditions of the past.

\section{Geological Framework}

Geological framework of Sulawesi is complex. This is due to the converging event between the three tectonic plates, there are Australia plate that moving northward, Pacific Plate that moving westward and Eurasian plate that moving southsoutheastward (Simanjuntak \& Barber, 1996, p. 185; Wibowo, 2016, pp. 17-18). Regarding to the research location in South Sulawesi, the tectonic dynamics is reflected by the forming of subsidence that most likely took place since the early Middle Miocene. The area of subsidence in Walanae depression is framing by two normal fault, there are the Walanae faults, which appear in the east, and the Soppeng fault that is only exposed in the west (Sartono, 1979, p. 73).

Later this Walanae depression then become a valley. The most important constituent form Walanae Valley is The Walanae River System with its tributaries. Rivers in Walanae Valley have a trellis pattern which characterize by straigth river linier along the valley where the tributatries comes from steep slopes from both sides. Walanae river as the main river forms perpendicular angle with its tributaries so it's like fence form (figure 1).

Based on the geological map sheet of Pangkajene and West part of Watampone Sukamto (1982) and Wibowo (2016, pp. 1718 ), rock formations in this area from old to young are Early Eosen-Late Oligocene Salo Kalupang Formation which is characterized by sandstone, shale and claystone, intercalated with volcanic conglomerate, brecciaes and tuff; Eosen Mallawa Formation that is composed by sandstone, conglomerate, siltstone, claystone and marl with insertion by thin layer or lenses coal and claystone; Middle-Late Miocene Camba Formation which is characterized by the intercalation of marine deposit-volcanic rock; Middle Miocene-Pliocene Walanae Formation that composed by sandstone intercalated with siltstone, tuff, marl, claystone, conglomerate and limestone that wide spread along Walanae River valley, on east part of Tempe Lake, and around Watampone. 
The Walanae Formation consists of the Tacipi Member, Soppeng Volcano Rocks and Quaternary Rocks. Tacipi member is composed of limestone with layered limestone, napal, claystone, sandstones and tuffs. Then Soppeng Volcano Rocks consists of volcanic and lava breccia, with tuffs of sand-grained tufa to lapili and claystone. While Quaternary rocks in the form of clay, silt, sand and gravel along the big river, around Lake Tempe and along the coast.

\section{METHODS}

The research is done in some stages, starting from the process of descripting the finding location by making the situation map and the local stratigraphic profile at the finding location. The description of the specimen is compared with the results of previous studies. Age analysis refers to the vertebrate fauna biostratigraphy of South Sulawesi by Van Den Bergh, et al. (2001), then the results of the study are discussed and synthesized into a conclusion.

\section{RESULT AND DISCUSSION}

\section{Description of the Specimen}

The BAM-041 is a maxilla of Stegodon with molars remain that only its root that are still recognizable. The characteristic of Stegodontidae tooth is where the enamel of its teeth is seen two layers and almost equal in its thickness(Van Den Bergh, 1999, p. 27). This feature of two enamel layers is still recognizable on the

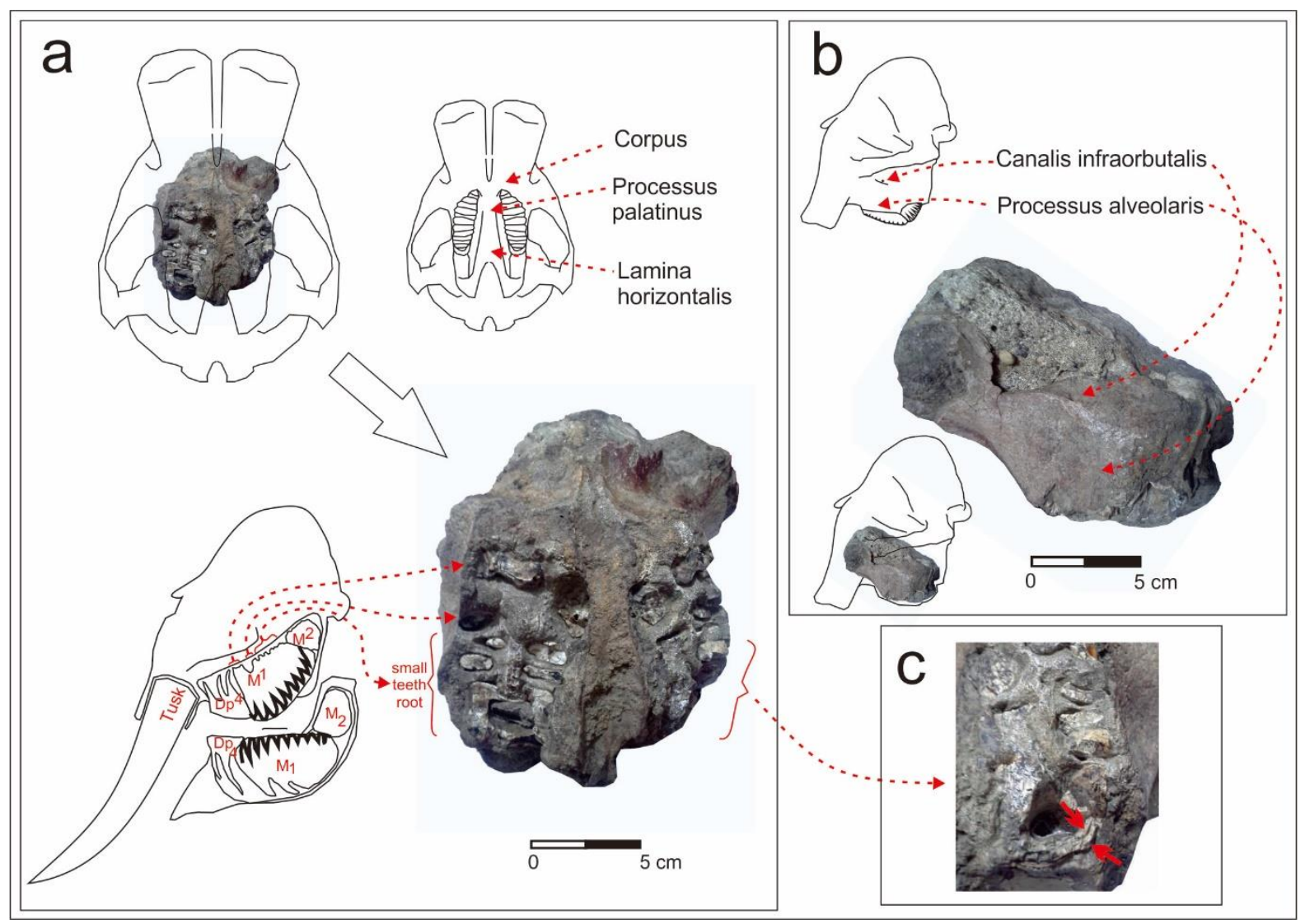

Figure 3. a. BAM-041 and its anatomical position in cranial proboscidae shows from the underside view of maxilla; b. BAM-041 specimen and its anatomical position in cranial proboscidae shows from the sinistral lateral view of maxilla; c. two enamel layers still recognizable on the BAM-041 pointed by red arrows (source: author, 2019). 
Table 1. Comparison of measurements of BAM-041 specimen with other Stegodon in mm. Ca: circa or approximation.

\begin{tabular}{|c|c|c|c|c|}
\hline & $\begin{array}{c}\text { Stegodon } \\
\text { Sompoensis } \\
\text { Dp }^{4} \\
\text { (Hooijer 1964) }\end{array}$ & $\begin{array}{c}\text { Stegodon } \\
\text { trigonocephalus } \\
\text { Dp }^{4} \\
\text { (Hooijer 1964) }\end{array}$ & $\begin{array}{c}\text { Stegodon } \\
\text { BAM-041 } \\
\text { M }^{1} \\
\text { (This research) }\end{array}$ & $\begin{array}{c}\text { Stegodon } \\
\text { trigonocephalus } \\
\mathbf{M}^{1} \\
\text { (Hooijer 1964) }\end{array}$ \\
\hline Length & Ca 50 & $90-108$ & 100 & $118-157$ \\
\hline Widht & 28 & $48-57,5$ & 50 & 59-Ca72 \\
\hline Ridge formula & $4 x$ & $x 7 x$ & $>5$ & $x 7 x-x 8 x$ \\
\hline
\end{tabular}

BAM-041 (figure 3c). In this specimen, the infraorbitalis canal hole is still found. This infraorbitalis canal hole is also one of the observation point for concluding the specimen is the maxilla (figure $3 b$ ). From the underside, some part of maxilla is still recognizable, there are the palatinus processus in the middle between the teeth, the corpus in the maxilla toward the ivory and the prosesus alveolaris (figure $3 \mathrm{a}$ ).

Teeth is one of the main characteristic that can be used to describe vertebrate fossil specimen. Based on this reason teeth comparison of Stegodon trigonocephalus and Stegodon sompoensis that had alive in Indonesia is done (table 1). Teeth of BAM-041 leaving only its root and a small part of teeth crown on the posterior part. The shape of the small part of teeth crown is similar to the genus Stegodon so that why we infer that this specimen is belong to Stegodon. The root of the right tooth is more complete compare to the left tooth. The shape of right tooth root is still recognizable that it has rectangular shape and in its posterior and anterior part tends to have the same width. This characteristic is belong to tooth upper Deciduous premolar4 $\left(\mathrm{Dp}^{4}\right)$, upper Molar1 $\left(\mathrm{M}^{1}\right)$ or upper Molar2 $\left(\mathrm{M}^{2}\right)$.

The next observation is the comparison between width and length tooth where BAM-041's tooth shows its width only a half by its length. This characteristic is belong to $\mathrm{Dp}^{4}$ and $\mathrm{M}^{1}$. Another point observation is the present of the small teeth roots as the representation of teeth ridges located behind the main tooth root (figure 2a). This characteristic is not found in $\mathrm{Dp}^{4}$ and only found in $\mathbf{M}^{1}$ to $\mathrm{M}^{3}$. All these facts show that the teeth of BAM-041 are $\mathrm{M}^{1}$.

Based on the number of the teeth root remains, it can be estimated that the ridge of $\mathrm{M}^{1}$ teeth is more than 5 pieces (table 1). The comparative data in table 1 shows that the Stegodon BAM-041 specimen has a small M1 which its size only 2/3 of $\mathbf{M}^{1}$ Stegodon trigonocephalus.

Refers to the data that the size of $\mathrm{M}^{1}$ BAM-041 is smaller than Stegodon trigonochepalus it can be concluded that the BAM-041 is a specimen of a dwarf Stegodon named Stegodon sompoensis. This conclusion supports the earlier assertion that Stegodon sompoensis is a type of dwarf Stegodon that once lived in South Sulawesi (Hooijer, 1964: 43; van den Bergh 1999: 12). The taxonomy of Stegodon sompoensis is:

Order Proboscidea Illiger, 1811

Family Stegodontidae Osborn, 1918

Genus Stegodon Falconer, 1857

Stegodon sompoensis Hooijer, 1964

\section{Location and geological age of specimen}

The BAM-041 was discovered in Ciangkange near Calio Museum with coordinate: $4^{\circ} 20^{\prime} 00.8^{\prime \prime} \mathrm{S} ; 120^{\circ} 01^{\prime} 18.1$ ' $\mathrm{E}$ (figure 2). The outcrops is near the road that characterized by sandstones layers with conglomerate. The conglomerate contains vertebrate fossils which is stratigraphically is the earliest layers of vertebrate fossil bearing lithology in this area. In the northern 


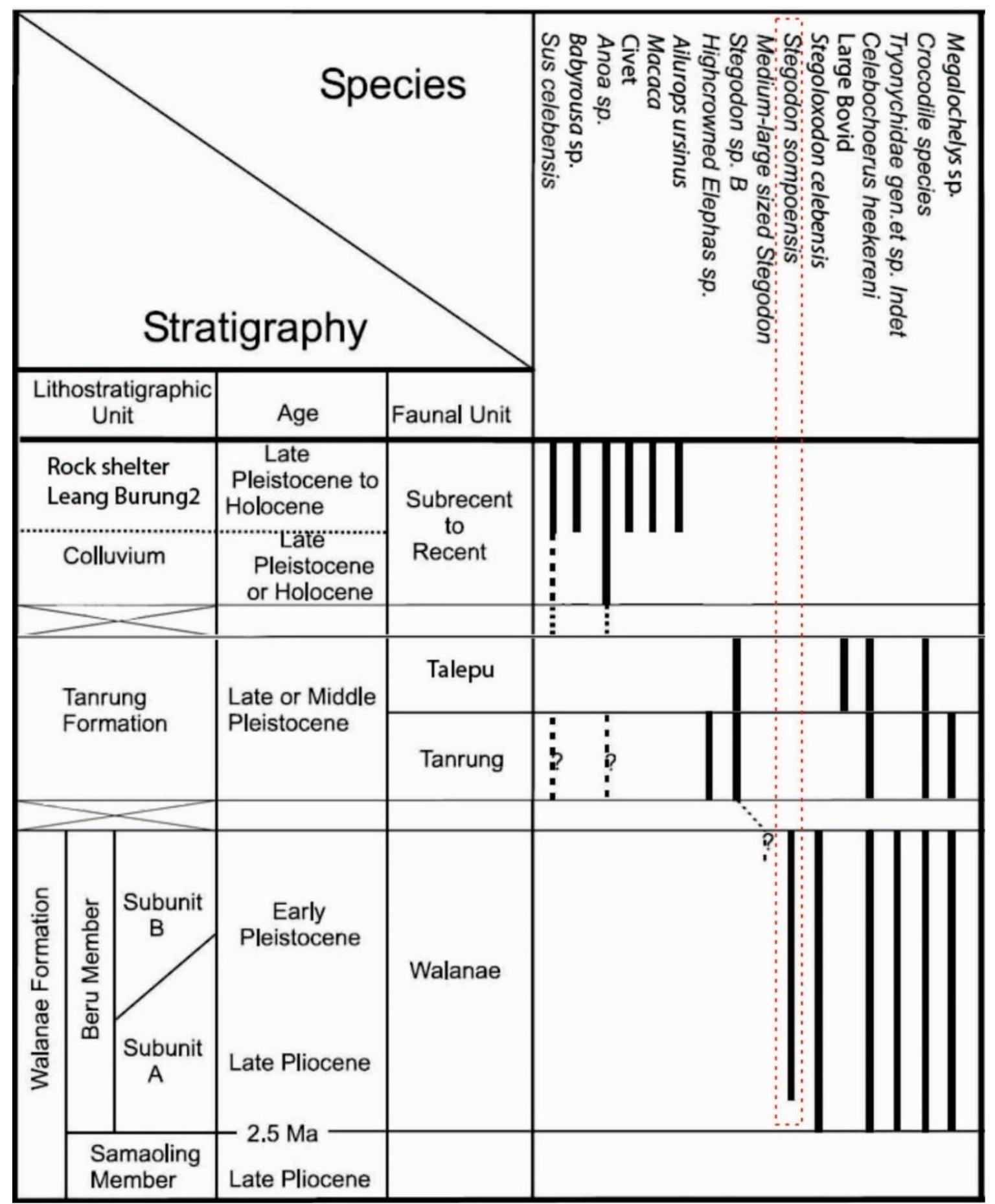

Figure 4. Vertebrate fauna biostratigraphic of South Sulawesi. Tanrung Fauna from van den Bergh, et al. 1994: 36, Fauna Talepu from van den Bergh, et al. 2016b: 210, Fauna Leang Burung 2 from Glover 1975 as reported by Brumm, et al. 2018: 4. Stegodon sompoensis is in the red dot box (source: van den Bergh, et al. 2001: 394, modified).

part of the road there is a layer about $\mathrm{N} 155 \mathrm{E} / 60^{\circ}$. In the southern part of the road, the outcrop is in the yard of the resident's house that already flattened to the surface of the ground, but the rock layers still can be observed.

The sedimentary matrix that still attached to the BAM-041 specimen is coarse 
sandstone. This characteristic is similar to the sandstone unit of the Walanae Formation. According to Sukamto (1982), Walanae Formation consists of sandstone intercalated with siltstone, tuff, marl, claystone, conglomerate and limestone.

Based on the sedimentary matrix on the specimens and also on the location of the findings which are then linked with the geological map in the Walanae valley area, the lithology unit at the site of the findings may be matched with the Beru subunit A of Walanae formation.

The fossil age of BAM-041 in this study is based on the relative age of the fossil bearing rock formation and vertebrate fauna biostratigraphy in the South Sulawesi region. The fossil bearing rock formation stated previously is the Beru Member of Walanae Formation that have age about 2.5 million years ago or Pliocene-Pleistocene (Van Den Bergh, Vos, \& Sondaar, 2001, p. 394; Wibowo, 2016, p. 13) (figure 4). This is the oldest bearing fossil from the upper part of the Walanae Formation. The age of 2.5 million years based on paleomagnetic and micro paleontological evidence (Van Den Bergh et al., 1994, p. 36).

\section{Discussion}

The genus of Stegodon was first introduced by Falconer in 1857 based on fossil from India which was originally regarded as an intermediate form between Mastodon and modern Elephant. Recently Stegodon is regarded as a different type of Mastodon or Elephant (Osborn, 1936, p. 25, 1942, p. 806), event in general, Stegodon is a genus of elephant family that are anatomically similar to the modern elephant (Saegusa, Thasod, \& Ratanasthien, 2005, p. $31)$.

Hooijer (Hooijer, 1964, p. 43) said that Stegodon sompoensis is a kind of dwarf Stegodon where this conclusion is based on its teeth characteristic and its small teeth size. The specimen from this species is very rare that makes our knowledge about this species also limited. Based on the molar size of BAM-041 which has a small $\mathrm{M}^{1}$ that it size only $2 / 3$ of $\mathrm{M}^{1}$ Stegodon trigonochepalus, so the BAM-041 specimen add to the evidence that Stegodon sompoensis is indeed a type of dwarf Stegodon.

Dwarf creatures are usually found in an isolated area (Van Den Bergh et al., 2016). Van Valen tries to explain this phenomenon with his theory called Island rule. Island rule states that vertebrate animals in an island generally tend to be large in small animals and become dwarfed in large animals. Regarding to the Stegodon sompoensis which is a dwarf Stegodon that lived in about 2.5 million years, it can be imply that in 2.5 million years ago the area of Soppeng, South Sulawesi was an isolated in territory.

Research on the Cabenge Site, Soppeng and its surrounding area always linked to the Plio-Pleistocene Walanae Formation (Van Den Bergh \& Aziz, 1995, p. 1; Van Den Bergh et al., 2001, p. 394). The Walanae Formation exposed in the Sengkang Anticline area is divided into 4 members (Suyono \& Kusnama, 2010, p. 9): Tacipi, Burecing, Samaoling and Beru.

Starting from the claystone which is a sea sediment from Burecing Member which then turned into intercalated sandstone-marl known as Samouling member (Sartono, 1979, p. 67; Van Den Bergh \& Aziz, 1995, p. 20). Limestones of Tacipi member are likely to form when this area was a shallow sea and inter fingering with Burecing Member. Above Samouling laid the Beru members who were exposed along the west wing of the Sengkang Anticline about 100 to $150 \mathrm{~m}$ from the Walanae Formation (Van Den Bergh \& Aziz, 1995, p. 22). Beru members are divided into 2 parts, Subunit A and Subunit B.

The subunit A is characterized by the inter fingering of terrestrial sediments with marine deposits represented by marine 


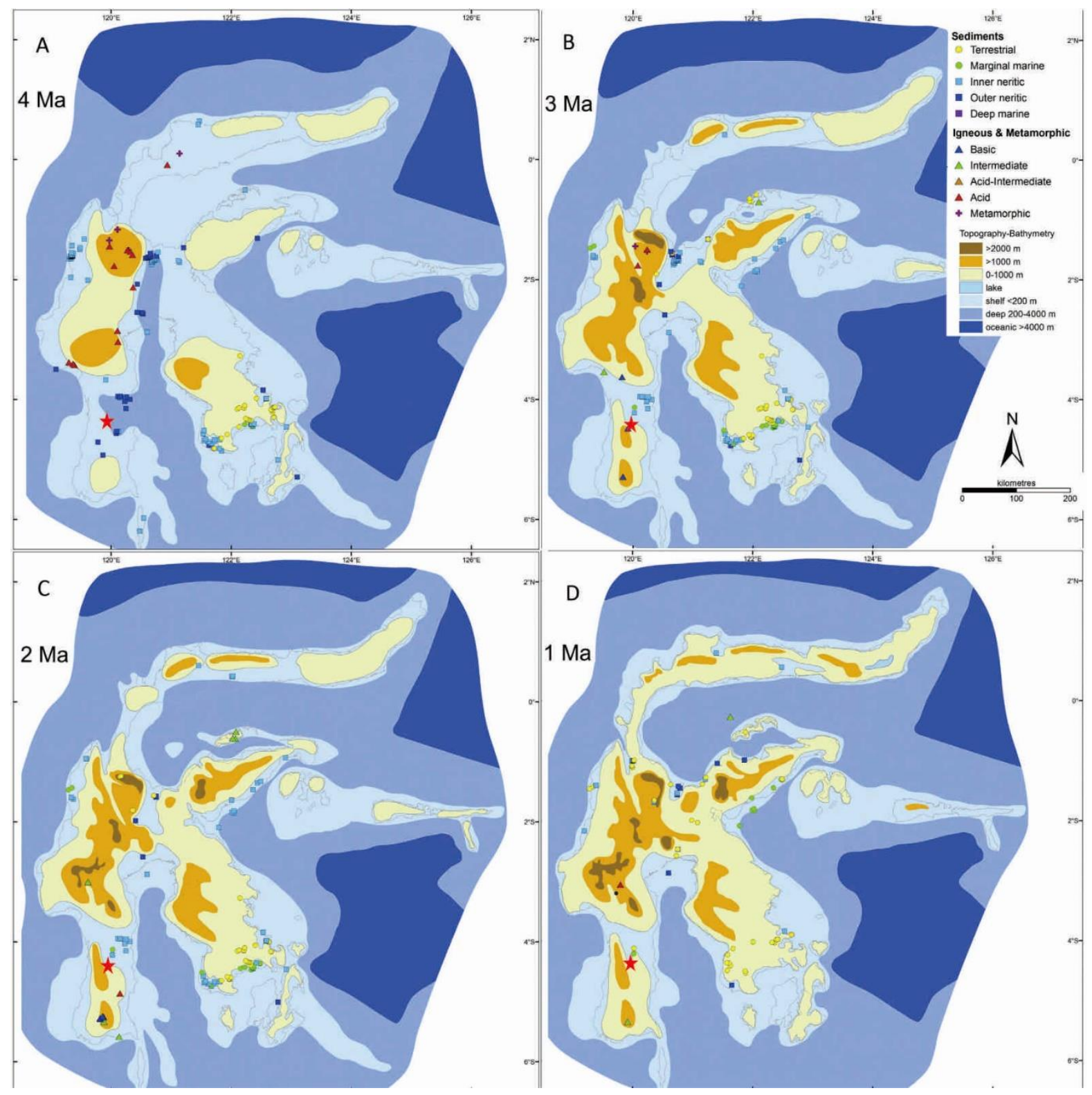

Figure 5. Palaeogeography of Sulawesi at at 4-1 Ma. Fossil find location indicated by red star symbol (Source: Nugraha and Hall 2018: 202, 204)

sandstones, lagoon mud and coastal sediments. Meanwhile, Subunit B is increasing in the grain size of sandstone that dominates the sediment (Van Den Bergh \& Aziz, 1995, p. 22) . The Subunit A was deposited around 2.5 million years ago / Plio-Pleistocene (figure 4) (Van Den Bergh et al., 2001, p. 394).

This research shows that the BAM041 was deposited in the sandstone of Beru member, Subunit A. This sandstone was deposited in the coastal-lagoon deposition environment (Suyono \& Kusnama, 2010, p. 9). Study of Cenozoic palaeogeography of Sulawesi by Nugraha and Hall (2018) also shows that at 4-1 Ma South Sulawesi was an isolated island (figure 5). So, it can be said that Stegodon sompoensis in the Walanae valley area during the Plio-Pleistocene period lived in an isolated area where the environment was a lowland environment near the coastal-lagoons.

Until now either in Sulawesi, the distribution of Stegodonts in South East Asia 
has been known so far also from Java Island, Lesser Sunda Islands (Flores, Sumba, Timor) and Philippines Islands (Aziz, 1990, p. 74). Furthermore, Stegodon fossil remains also found in Sangihe Island, a small island north of Sulawesi Island. In the case of vertebrate migration route in the past, Sangihe Island location is interesting because it lying between Philippines Island and Sulawesi Island (Aziz, 1990, p. 75).

Based on all facts that states before, two hypotheses were emerged regarding to the case of the ancestor and the migration pattern of Stegodon in Sulawesi Island. The first hypothesis is the ancestor of Stegodon in South Sulawesi was migrated from north area or from Phlilippines. The second hypothesis is the ancestor of Stegodon especially Stegodon fossil remains that found in Walanae Valley could be from Java and Lesser Sunda Islands (Flores, Sumbas, Timor).

The discovery of Celebochoerus (an archaic suid) in Philipines (Ingicco et al., 2016, p. 10, 2018) support the hypothesis that paleomamal of South Sulawesi include Stegodon was from Philipines because Celebochoerus also found in South Sulawesi, but the discovery of Stegoloxodon (another genera of proboscidea) in South Sulawesi also support the hypothesis that Sulawesi Stegodon was from Java because Stegoloxodon also found in Java (Wibowo et al., 2015, p. 356). The presence of Stegodon fossil remains in South Sulawesi that found associated with Stegoloxodon and Celebochoerus makes two hypothesis that state before still unresolve. This is why the existence of Stegodon fossils in South Sulawesi is still debatable regarding to who is the ancestor of this Sulawesi Stegodon and how they migrated to South Sulawesi in the past.

\section{CONCLUSION}

This study support the statement that Stegodon sompoensis is a dwarf type of Stegodon which is about $2 / 3$ the size of Stegodon trigonochepalus from Jawa Island. The BAM-041 specimen is a maxillary fragment with upper molar1 $\left(\mathrm{M}^{1}\right)$ of Stegodon sompoensis that lived in the lowlands near the coastal-lagoons about 2.5 million years ago in the Walanae valley, South Sulawesi. In the future, detailed mapping of the area should be completed with absolute dating analyzes to clarify the space and time positions of the fossils found in this area.

\section{ACKNOWLEDGEMENT}

We gratefully acknowledge the Makassar Archaeology Office for providing funding, specimen and facilities in this research. We would like to express our deep appreciation to Dr. Muhammad Ma'ruf Mukti (Geotechnology LIPI) and Dr. Yuliana Susilawati (LIPI) for their guidance during the writing of this paper and Mr. Anwar Akib for sharing his knowledge about Walanae Site.

$$
* * * * * *
$$

\section{REFERENCES}

Agenbroad, L. D. (2012). Giants and pygmies: mammoths of Santa Rosa Island, California (USA). Quaternary International, 255, 2-8. https://doi.org/10.1016/j.quaint.2011.03.044 Aziz, F. (1990). Pleistocene Mammal Faunas of Sulawesi and Their Bearings to Paleozoogeography. Kyoto University, Japan.

Bartstra, G. J. (1997). A fifty years commemoration: fossil vertebrates and stone tools in the Walanae valley, South Sulawesi, Indonesia. Quartar, 47, 29-50.

Bartstra, G. J., Hooijer, D. A., Kaluppa, B., \& Akib, M. A. (1994). Notes on fossil vertebrates 
and stone tools from Sulawesi, and the stratigraphy of the northern Walanae Depression. Palaeohistoria, 33/34, 1-18.

Brumm, A., Hakim, B., Ramli, M., Aubert, M., Bergh, G. D. Van Den, Li, B., ... Morwood, M. J. (2018). A Reassessment of the early archaeological record at Leang Burung 2, a Late Pleistocene rock-shelter site on the Indonesian island of Sulawesi. Plos One, April, 1-43. https://doi.org/doi.org/10.1371/journal.pone.0193025.g001

Geer, A. A. E. van der, Lyras, G., Vos, J. de, \& Dermitzakis, M. (2010). Evolution of Island Mammals: Adaptation and Extinction of Placental Mammals on Islands. https://doi.org/10.1002/9781444323986

Geer, A. A. E. van der, \& Van Den Bergh, G. D. (2016). The effect of area and isolation on insular dwarf proboscideans. Journal of Biogeography. https://doi.org/10.1111/jbi.12743

Heekeren, V. H. (1958). The Tjabenge flake industry from South Celebes. Asian Perspectives, 2, 77-81.

Herridge, V. (2010). Dwarf elephants on Mediterranean islands: A natural experiment in parallel evolution. University College, London.

Hooijer, D. A. (1949). Pleistocene Vertebrates from Celebes IV: Archidiskodon celebensis nov.spec. Zool. Meded, 30(14), 205-226.

Hooijer, D. A. (1955). Fossil Proboscidea from the Malay Archipelago and India. Zool. Verh., 28, 1-146.

Hooijer, D. A. (1964). Pleistocene vertebrates from Celebes XII: Notes on Pigmy Stegodons. Zoologische Mededelingen, 40(7), 37-45.

Ingicco, T., Van Den Bergh, G. D., De Vos, J., Castro, A., Amano, N., \& Bautista, A. (2016). A new species of Celebochoerus (Suidae, Mammalia) from the Philippines and the paleobiogeography of the genus Celebochoerus Hooijer, 1948. Geobios, 49(4), 285-291. https://doi.org/10.1016/j.geobios.2016.05.006

Ingicco, T., Van Den Bergh, G. D., Jago-On, C., Bahain, J. J., Chacón, M. G., Amano, N., ... De Vos, J. (2018). Earliest known hominin activity in the Philippines by 709 thousand years ago. Nature, 557, 233-237.

Markov, G. N., \& Saegusa, H. (2008). On the validity of Stegoloxodon Kretzoi, 1950 (Mammalia: Proboscidea). Zootaxa, 1861, 55-56. Retrieved from www.mapress.com/zootaxa/

Morwood, M. J., Sutikna, T., Saptomo, E. W., Jatmiko, Hobbs, D., \& Westway, K. E. (2009). Preface: research at Liang Bua, Flores, Indonesia. Journal of Human Evolution, 57(5), 437-449. https://doi.org/10.1016/j.jhevol.2009.07.003

Nugraha, A. M. S., \& Hall, R. (2018). Late Cenozoic palaeogeography of Sulawesi, Indonesia. Palaeogeography, Palaeoclimatology, Palaeoecology, 490, 191-209. https://doi.org/10.1016/j.palaeo.2017.10.033

Osborn, H. F. (1936). Proboscidea, Volume I. New York: Amer. Mus. Press.

Osborn, H. F. (1942). Proboscidea, Volume II. New York: . Amer. Mus. Press.

Raia, P., \& Meiri, S. (2006). The island rule in large mammals: paleontology meets ecology. Evolution, 60, 1731-1742.

Rozzi, R. (2017). A new extinct dwarfed buffalo from Sulawesi and the evolution of the subgenus Anoa: an interdisciplinary perspective. Quaternary Science Reviews, 157, 188205. https://doi.org/10.1016/j.quascirev.2016.12.011

Saegusa, H., Thasod, Y., \& Ratanasthien. (2005). Notes on Asian Stegodontids. Quaternary International, 126-128, 31-48.

Saiful, A. M., Wibowo, U. P., Hakim, B., \& Akib, A. (2016). Fauna Vertebrata Lembah 
Walennae dan Unsur Budaya Pleistosen. In Hasanuddin \& B. A. K. W (Eds.), Lembah Walennae, Lingkungan Purba dan Jejak Arkeologi Peradaban Soppeng. Makassar: Ombak.

Sartono, S. (1979). The Age of the Vertebrate Fossils and Artefacts from Cabenge in South Sulawesi, Indonesia. Mod Quaternary Res. SE Asia, 5, 65-81.

Simanjuntak, T. O., \& Barber, A. J. (1996). Contrasting tectonic styles in the Neogene orogenic belts of Indonesia. In Tectonic evolution of Southeast Asia (pp. 185-201). London: Geological Society Special Publication.

Simpson, G. G. (1977). Too Many Lines; The Limits of the Oriental and Australian Zoogeographic Regions. Proceeding of the American Philosophical Society, 107-120.

Stelbrink, B., Albrecht, C., Hall, R., \& Rintelen, T. von. (2012). The biogeography of Sulawesi revisited: is there evidence for a vicariant origin of taxa on Wallace's "anomalous island"? Evolution, 66, 2252-2271.

Sukamto, R. (1982). Peta Geologi Lembar Pangkajene dan Watampone Bagian Barat Sulawesi, Skala 1:250.000. Bandung: Pusat Penelitian dan Pengembangan Geologi.

Suyono, \& Kusnama. (2010). Stratigraphy and Tectonics of the Sengkang Basin, South Sulawesi. Jurnal Geologi Indonesia, 5(1), 1-11.

Van Den Bergh, G. D. (1999). The Late Neogene elephantoid-bearing faunas of Indonesia and their palaeozoogeographic implications; a study of the terrestrial faunal succession of Sulawesi, Flores and Java, including evidence for early hominid dispersal east of Wallace's Line. Scripta Geologica, 117, 1-419.

Van Den Bergh, G. D., \& Aziz, F. A. (1995). The Geology and Stratigraphy of the VertebrateBearing deposits in the Sengkang Basin: The Terrestrial Faunal Evolution of South Sulawesi during the Late Pliocene and Quaternary. Dutch-Indonesia Joint Research Group on the Sedimentology and Vertebrate Pal (Special Pu). Bandung: Geological Research and Development Center (GRDC).

Van Den Bergh, G. D., Aziz, F. A., Sondaar, P. Y., \& Vos, J. de. (1994). The first Stegodon fossils from Central Sulawesi and a new advanced Elephas species from South Sulawesi. Bulletin Geological Research and Development Centre, 17, 22-39.

Van Den Bergh, G. D., Kaifu, Y., Kurniawan, I., Kono, R. T., Brumm, A., Setiyabudi, E., ... Morwood, M. J. (2016). Homo floresiensis-like fossils from the early Middle Pleistocene of Flores. Nature, 534, 245-248. https://doi.org/10.1038/nature17999

Van Den Bergh, G. D., Vos, J. de, \& Sondaar, P. Y. (2001). The Late Quaternary palaeogeography of mammal evolution in the Indonesian Archipelago. Palaeogeography, Palaeoclimatology, Palaeoecology, 171, 385-405.

Van, L. V. (1973). Pattern and the balance of nature. Evolutionary Theory, 1, 31-49.

Vos, J. de, Ostende, H., \& Van Den Bergh, G. D. (2007). Patterns in Insular Evolution of Mammals: A Key to Island Palaeogeography. In W. Renema (Ed.), Biogeography, Time, and Place: Distributions, Barriers, and Islands (pp. 315-345). Spriger.

Wibowo, U. P. (2016). Geoarkeologi Soppeng: Lingkungan Purba. In Hasanuddin \& B. A. K. W (Eds.), Lingkungan Purba dan Jejak Arkeologi Peradaban Soppeng. Makassar: Ombak.

Wibowo, U. P., Setiyabudi, E., Kurniawan, I., \& Insani, H. (2015). Indonesian Archipelago Paleogeography as the Natural Laboratory of the Proboscidean Migration and Adaptation Pattern. Proceedings Joint Convention Balikpapan, 355-388. HAGI-IAGI-IAFMIIATMI. 